\title{
Nurr1-RXR heterodimers mediate RXR ligand-induced signaling in neuronal cells
}

\author{
Åsa Wallén-Mackenzie, ${ }^{1}$ Alexander Mata de Urquiza, ${ }^{1}$ Susanna Petersson, ${ }^{1,5}$ \\ Francisco J. Rodriguez, ${ }^{2,5}$ Stina Friling, ${ }^{1,5}$ Joseph Wagner, ${ }^{2}$ Peter Ordentlich, ${ }^{3}$ Johan Lengqvist, ${ }^{1}$ \\ Richard A. Heyman, ${ }^{3}$ Ernest Arenas, ${ }^{2}$ and Thomas Perlmann ${ }^{1,4,6}$ \\ ${ }^{1}$ The Ludwig Institute for Cancer Research, Stockholm Branch, S-171 77 Stockholm, Sweden; ${ }^{2}$ Laboratory of Molecular \\ Neurobiology, Department of Medical Biochemistry and Biophysics, Karolinska Institutet, S-171 77 Stockholm, Sweden; \\ ${ }^{3}$ X-Ceptor Pharmaceuticals Inc., San Diego, California 92121, USA; ${ }^{4}$ Department of Cell and Molecular Biology, Karolinska \\ Institutet, S-171 77 Stockholm, Sweden
}

The retinoid $\mathrm{X}$ receptor $(\mathrm{RXR})$ is essential as a common heterodimerization partner of several nuclear receptors (NRs). However, its function as a bona fide receptor for endogenous ligands has remained poorly understood. Such a role would depend on the existence of RXR activating ligands in vivo and on the ability of such ligands to influence relevant biological functions. Here we demonstrate the presence of endogenous RXR ligands in the embryonic central nervous system (CNS) and show that they can activate heterodimers formed between RXR and the orphan NR Nurr1 in vivo. Moreover, RXR ligands increase the number of surviving dopaminergic cells and other neurons in a process mediated by Nurr1-RXR heterodimers. These results provide evidence for a role of Nurr1 as a ligand-independent partner of RXR in its function as a bona fide ligand-activated NR. Finally, our findings identify RXR-Nurr1 heterodimers as a potential target in the treatment of neurodegenerative disease.

[Keywords: Nuclear receptor; orphan receptor; retinoid X receptor; dopamine neurons; neuronal survival]

Received June 23, 2003; revised version accepted October 28, 2003.

Nuclear receptors (NRs) constitute a conserved family of ligand-activated transcription factors including receptors for estrogen, thyroid hormone, vitamin $\mathrm{D}$, and retinoids, but also a large group of receptors lacking identified ligands, referred to as orphan receptors (Giguère 1999; Aranda and Pascual 2001). Several NRs, including, for example, the retinoic acid receptor (RAR) and thyroid hormone receptor, require heterodimerization with the common partner the retinoid X receptor, or RXR (NR2B1-3), for efficient DNA binding and function in response to their cognate ligands (Mangelsdorf et al. 1990; Mangelsdorf and Evans 1995). RXR can also bind ligands such as 9-cis-retinoic acid (9cis RA) and fatty acids including the brain-enriched docosahexanoic acid (DHA; Mangelsdorf and Evans 1995; Mata de Urquiza et al. 2000). However, given its essential function as a heterodimerization partner/cofactor, it has remained possible that RXR's only role might be to provide silent support to other members of the NR family, and definitive evidence for a function as a true "signaling" NR in vivo has so far been lacking.

\footnotetext{
${ }^{5}$ These authors contributed equally to this work.

${ }^{6}$ Corresponding author.

E-MAIL Thomas.Perlmann@licr.ki.se; FAX 46-8-33-28-12.

Article published online ahead of print. Article and publication date are at http://www.genesdev.org/cgi/doi/10.1101/gad.276003.
}

The possibility that RXR may be activated by endogenous ligands also raises questions concerning the identity of relevant RXR partners in such signaling events. RXR is unable to respond to cognate RXR ligands in several so-called nonpermissive heterodimers (Mangelsdorf and Evans 1995; Germain et al. 2002). However, ligand activation can occur in "permissive" heterodimeric complexes with other NRs (Mangelsdorf and Evans 1995). The orphan NR Nurr1 (NR4A2) forms heterodimers with RXR that are robustly activated by RXR ligands (Law et al. 1992; Forman et al. 1995; Perlmann and Jansson 1995), but can also bind to specific DNAbinding sites either as monomers or homodimers and function as a constitutively active transcription factor (Wilson et al. 1993; Philips et al. 1997). Interestingly, Nurr1 lacks a cavity for ligand binding as revealed from the recently solved X-ray crystal structure of the Nurr1 ligand binding domain (LBD; Wang et al. 2003). Nurrl is thus distinct from other known RXR partners, which are all capable of binding cognate ligands.

Nurr1 is almost exclusively confined to the central nervous system (CNS) and is essential for the development of midbrain dopamine (DA) neurons (Zetterström et al. 1997; Castillo et al. 1998; Saucedo-Cardenas et al. 1998; Le et al. 1999a; Wallén et al. 1999|. In addition, analyses of Nurr1 heterozygous mutant mice show that DA neurons from these animals are more vulnerable to toxic stress compared with wild-type animals, indicating 
that Nurrl has a role in neuroprotection of mature DA cells (Le et al. 1999b; Eells et al. 2002). Indeed, recent identification of mutations in the human Nurr1 gene in familial cases of Parkinson's disease have provided clinically relevant evidence for such a role (Le et al. 2003).

Nurr1 is not only expressed in developing and mature DA neurons but is also localized to several additional brain areas including the hippocampus and cerebral cortex (Zetterström et al. 1996a,b). In addition, Nurr1 and its highly homologous family members NGFI-B (NR4A1) and Nor1 (NR4A3) can be rapidly induced by various stimuli, including hypoxic/ischemic stress and kainic acid-induced excitotoxicity (Law et al. 1992; NeumannHaefelin et al. 1994; Lin et al. 1996; Crispino et al. 1998; Honkaniemi and Sharp 1999; Johansson et al. 2000). It seems likely, therefore, that Nurrl functions in neuroprotection and/or other neuronal processes are not limited to dopaminergic cells.

Here we provide evidence showing that RXR is active in Nurr1-RXR heterodimers in the developing CNS in vivo. Moreover, regions in which Nurrl-RXR heterodimers are active contain endogenous RXR ligand activities. Finally, in experiments using neuronal primary cultures, we reveal that RXR ligands increase the number of surviving DA cells via a mechanism that requires ligand binding to RXR in Nurrl-RXR heterodimers. Thus, these findings provide evidence for active RXR signaling in vivo, demonstrate a functional role for Nurr 1 as a ligand-independent partner of RXR, and suggest a role of RXR ligands in neuronal cell survival.

\section{Results}

\section{Endogenous RXR ligands in the embryonic CNS}

We have previously used transgenic mice to assess activation of NR LBDs in vivo as a strategy to facilitate characterization of ligand distribution and NR function (Solomin et al. 1998; Mata de Urquiza et al. 1999). To analyze the activity of the Nurr1 LBD in vivo, a DNA sequence encoding a fusion protein of the Nurr1 LBD fused to the DNA-binding domain of the yeast transcription factor Gal4 was cloned into a transgenic vector also containing a LacZ reporter with upstream Gal4-binding sites. In transgenic mice, this approach allows analysis by X-gal staining of sites in vivo where Gal4-Nurr1 is active and thereby inducing the LacZ reporter gene. XGal staining of transgenic embryonic day 11.5 (E11.5) embryos revealed robust LacZ expression in several regions of the CNS including the cerebral cortex, medulla oblongata, spinal cord, and in the ventral midbrain (VMB) where DA neurons develop (Fig. 1A; data not shown). Moreover, staining was also seen in the proximal parts of the developing limbs (data not shown).

A
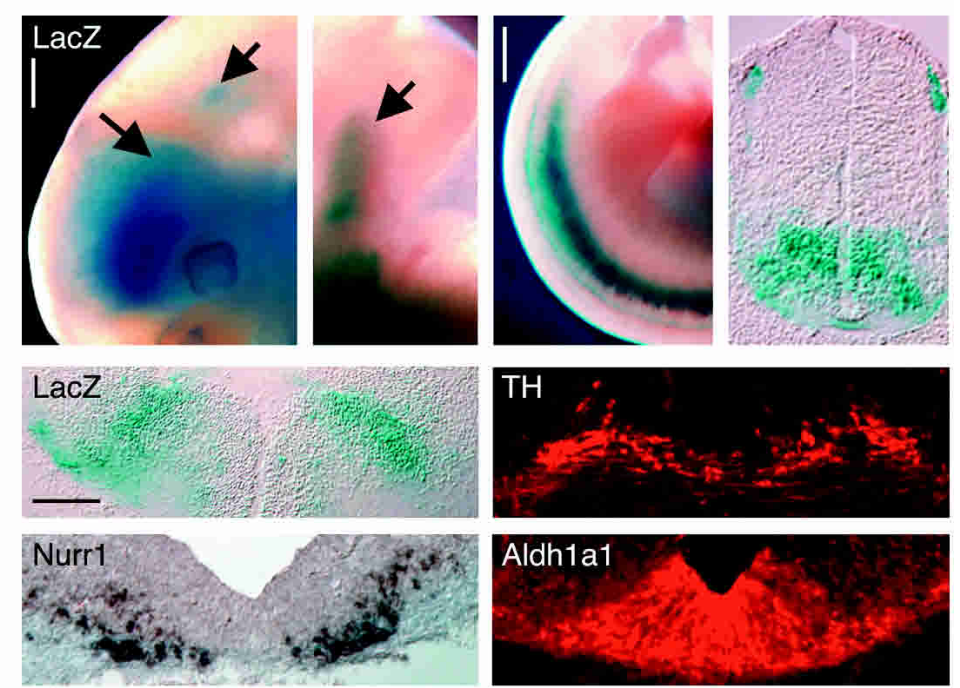

B

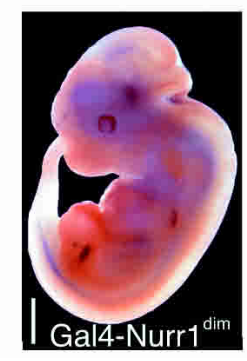

C

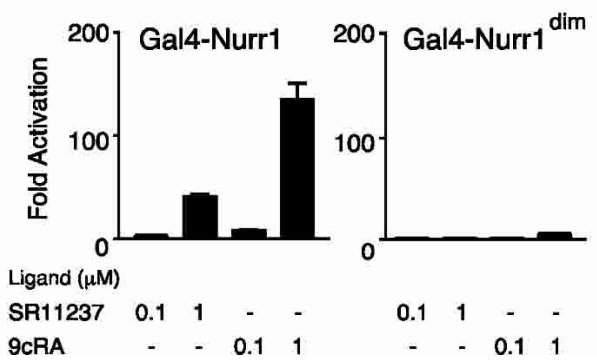

Figure 1. Gal4-Nurr1- and RXR-dependent activity localized in the ventral midbrain of Gal4-Nurr1 transgenic mice. (A, Top panel) Closeups of whole-mount X-gal-stained Gal4-Nurrl embryos displaying blue staining in the forebrain (lower arrow, top left picture), VMB (upper arrow, top left picture), medulla (middle left), and spinal cord (middle right). Cross-section through the spinal cord revealed the main staining to be localized ventrally and dorsolaterally (right picture). Bars: left, $480 \mu \mathrm{m}$ (also applies for middle left); middle right, $1000 \mu \mathrm{m}$; and right, $140 \mu \mathrm{m}$. (Middle and lower panels) Coronal sections from a representative Gal4Nurr1 transgenic embryo at E11.5 showing X-gal staining in the ventral midbrain (left, top section) in the region where also the dopaminergic markers Nurr1 mRNA (left, bottom section) and TH immunoreactivity (right, top section) can be seen, as well as retinaldehydrogenase Aldhla1 (right, bottom section), which is expressed in the DA progenitor cells. Bar, $100 \mu \mathrm{m} .(B)$ Whole-mount, representative picture of Gal4-Nurr1 ${ }^{\text {dim }}$ embryo, which lacks blue X-gal staining in the entire CNS. Bar, $1500 \mu \mathrm{m} .(C)$ Treatment of transiently transfected JEG3 cells. Gal4-Nurr1 or Gal4-Nurr1 ${ }^{\text {dim }}$ and human $\mathrm{RXR} \alpha$ expression vectors were cotransfected with a luciferase reporter gene containing Gal4-binding sites. An expression vector expressing $\beta$-galactosidase was used as an internal control. Cells were treated with or without RXR ligands. 
Coronal sections through the midbrain revealed LacZ staining in both the ventricular and mantle zones of the VMB. Staining correlated with that of Nurr1 mRNA expression and $\mathrm{TH}$ immunoreactivity (IR) in the mantle zone, suggesting that Gal4-Nurr1 was active in developing DA neurons (Fig. 1A). Within the ventricular zone, staining was localized to a domain expressing Aldh1a1, an aldehydrogenase previously shown to be expressed in proliferating DA progenitor cells as well as in maturing postmitotic DA neurons (Fig. 1A; Wallén et al. 1999).

Next, we asked if Gal4-Nurr1 activation required heterodimerization with RXR. A mutation in the LBD of Nurr1 (P560A) has previously been described and shown to disrupt dimerization with RXR (Aarnisalo et al. 2002). This mutation does not disrupt other functions such as DNA binding or the ability of the Nurr1 LBD to promote transcriptional activation in certain cell lines (Aarnisalo et al. 2002). The mutation was introduced in Gal4-Nurr1 to generate the dimerization-deficient derivative Gal4Nurr ${ }^{\text {dim }}$. Strikingly, in Gal4-Nurr $1^{\text {dim }}$ transgenic embryos, the CNS was not stained by X-gal, although staining similar to that observed in Gal4-Nurr1 embryos was detected in the limbs (Fig. 1B; data not shown). Nine out of $19(47 \%)$ Gal4-Nurr1 and 0 out of $17(0 \%)$ Gal4Nurr ${ }^{\text {dim }}$ embryos showed X-gal staining in the CNS. Because all these embryos represent independent transgenic integration events, the data clearly demonstrate that in E11.5 CNS, activation of Gal4-Nurr1 is entirely dependent on dimerization with RXR.

The results suggest that CNS activation of Gal4Nurrl might depend on ligand-mediated activation of the heterodimerization partner RXR. Indeed, reporter gene analysis in cell transfection experiments demonstrated that Gal4-Nurr1 functions as a sensor of RXR ligand activation (Fig. 1C). In contrast, Gal4-Nurr $1^{\text {dim }}$ was entirely inactive even when cells were treated with high doses of RXR ligands (Fig. 1C). In conclusion, our data suggest that Gal4-Nurr1 can be activated via RXR in vivo and that endogenous RXR ligands are present in several embryonic regions including the developing VMB.

In vitro reporter gene assays were used to analyze if embryonic VMB tissue explants, added to transfected human chorion carcinoma JEG-3 cells, contain and release RXR ligand activity. Consistent with data in transgenic embryos, VMB tissue activated Gal4-Nurr1 but failed to

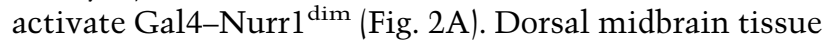
did not activate Gal4-Nurr1, consistent with the absence of X-gal staining in this region. Importantly, the RXR-specific antagonist LG849 (Sockanathan and Jessell 1998; Solomin et al. 1998), added together with VMB tissue, blocked activation of the reporter gene, demonstrating that Gal4-Nurrl activation was mediated via heterodimerization with ligand-bound RXR (Fig. 2B). Equal amounts of VMB tissue from stages E13.5-E15.5 were incubated with the Gal4-Nurrl-transfected reporter cells. A significant increase in activity was observed with increasing age (Fig. 2C), suggestive of an agedependent accumulation of RXR-specific ligand activity.

The endogenous RXR ligand 9cis RA activates both
RAR and RXR. A titration of 9cis RA in cells transfected with a Gal4-RAR expression vector demonstrated efficient activation at all tested concentrations (data not shown). In contrast, VMB tissue explants failed to activate Gal4-RAR, demonstrating that the endogenous activity was pharmacologically distinct from 9cis RA. The same activation profile was observed for tissue explants derived from the cortex, an additional brain area where X-gal staining revealed Gal4-Nurr1 activity (Fig. 2D).

The tissue activity was further characterized after partial purification. Activity from $\sim 80$ E15.5 mouse midbrains and cortices was recovered after hexane extraction and tested in a reporter gene assay (Fig. 2E). The most active fraction from reversed phase high performance liquid chromatography (HPLC; fraction \#4) was reconstituted and analyzed by negative ion mass spectrometry (Fig. 2F). The previously identified RXR ligand DHA (Mata de Urquiza et al. 2000) was the main constituent in this fraction (Fig. 2F). No detectable levels of 9cis RA were observed. Additional fractions showed limited activity and contained other fatty acid derivatives but no detectable levels of 9cisRA (data not shown). Because the active fraction is not purified to homogeneity, the active substance cannot be conclusively identified from these data. However, the experiments provide additional clues regarding its chemical properties and indicate that it is distinct from any known retinoid derivatives.

\section{$R X R$ ligands increase the number of surviving cultured DA neurons}

The accumulation of RXR ligand with increasing embryonic age and their abundance in the postnatal brain suggest a possible role in maturing and postnatal neurons (Fig. 2C; Mata de Urquiza et al. 2000). To assess the consequences of exogenously administered RXR ligands on VMB neuronal cells, we used primary rat cell cultures from E14.5-E15.5 VMB, a stage when DA cell fate commitment is already determined (Hynes and Rosenthal 1999). Mesencephalic TH-positive neurons degenerate progressively when maintained in a serum-free culture medium, and these cultures are therefore used to assay for survival-promoting factors (see, e.g., Hyman et al. 1991; Lin et al. 1993; Branton and Clarke 1999|. DA cells constituted $\sim 2 \%-5 \%$ of total cells in the VMB cultures and expressed the characteristic marker genes Nurr1, $\mathrm{TH}$, and Aldhlal (Fig. 3A; data not shown). By treating cells with the synthetic RXR-specific agonist LG100268 (hereafter referred to as LG268; Boehm et al. 1995; Repa et al. 2000), a dose-dependent increase in the number of surviving TH-positive neurons was observed, reaching $100 \%$ with the most effective concentrations 0.03 and $0.1 \mu \mathrm{M}$ (Fig. 3B). A similar concentration-dependent increase in the number of TH-positive neurons was also seen using a different RXR agonist (SR11237; Fig. 3B; data not shown; Lehmann et al. 1992). The observed increase in the number of surviving DA neurons could be due to an RXR-ligand-induced effect on neuronal proliferation rather than survival. However, the increase in $\mathrm{TH}$-positive neurons was not correlated with an in- 
A

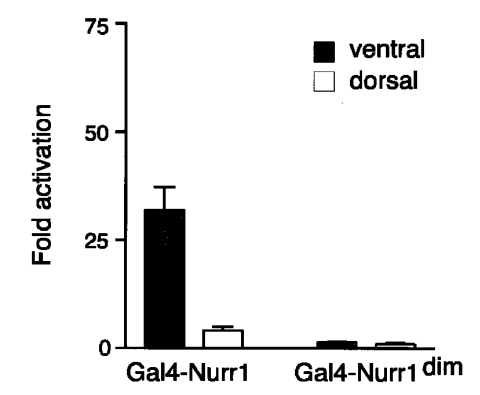

D

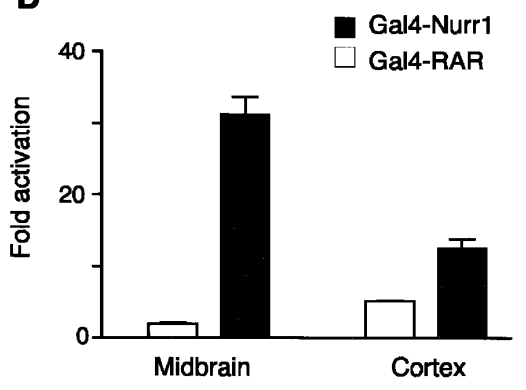

B

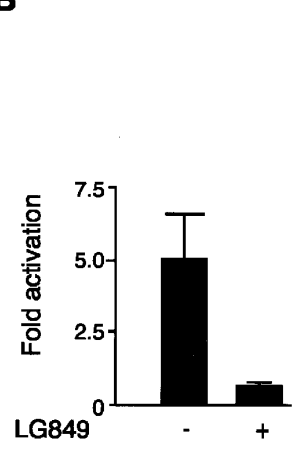

$\mathbf{E}$

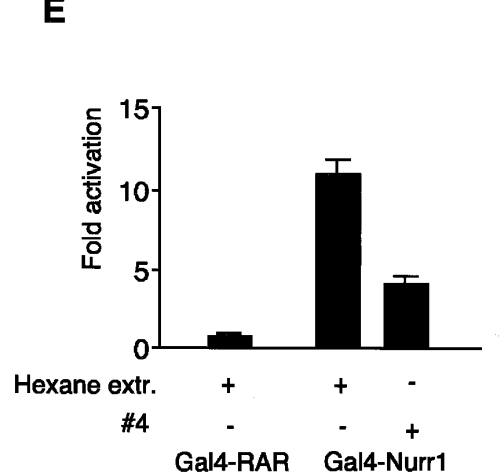

C

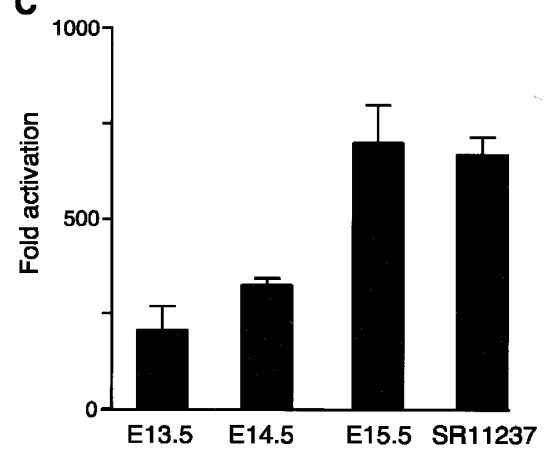

$\mathbf{F}$

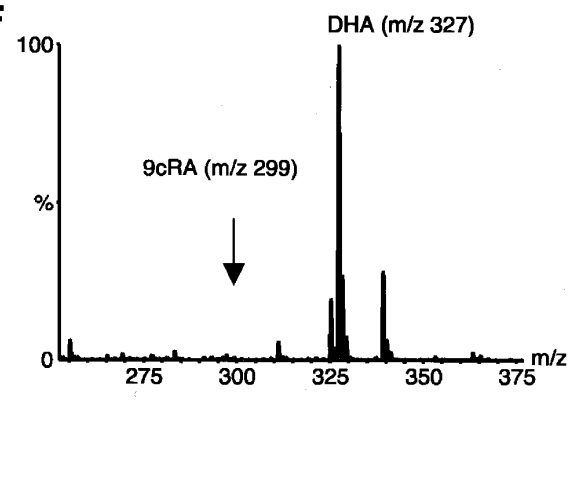

Figure 2. Wild-type ventral midbrain tissue activates a reporter gene assay in an RXR-dependent manner. $(A, B)$ Excised tissue from E12.5 dorsal and ventral midbrain of wild-type mice was placed on JEG-3 cells transiently transfected as in Fig. 1 with Gal4-Nurr1 and Gal4-Nurr1 ${ }^{\text {dim }}$ expression vectors, respectively. Activity of the reporter gene was analyzed $32 \mathrm{~h}$ posttransfection. Actual luciferase values vary between experiments because of differences in transfection efficiencies. Values are therefore given as "Fold activation." Results were consistent in at least three independent experiments. The value 1 is set as the activation obtained with indicated Gal4 constructs cotransfected with luciferase reporter but without addition of ligands or conditioned medium. $(A)$ Ventral midbrain tissue activates Gal4-Nurr1, whereas dorsal midbrain tissue did not result in significant reporter gene activation. Typically, E13.5 ventral midbrain tissue activated at 10\%-30\% of the level achieved with $1 \mu$ M SR11237 (129-fold activation with SR11237 in the displayed experiment). (B) Addition of the RXR-specific antagonist LG849 blocked activation by Gal4-Nurr1 in cells cultured together with ventral midbrain tissue. $(C)$ Reporter gene analysis of VMB activity from E13.5, E14.5, and E15.5 embryos shows that it increases with age. Very high levels of activation are seen when E15.5-conditioned medium is administered to transfected cells. In this particular experiment, E15.5-ventral-tissue-conditioned medium resulted in activation at levels seen with $1 \mu$ M SR11237. (D) Midbrain and cortex tissues do not activate RAR. Activity of midbrain and cortex tissue was assayed as above in cells expressing either Gal4-RAR or Gal4-Nurr1, respectively. (E) Partial purification of tissue-derived activity from mouse midbrain/cortex and analysis by negative ion mass spectrometry. Hexane extract as well as the most active HPLC fraction contained activity that stimulated cotransfected Gal4-Nurr1/RXR but not Gal4-RAR. (F) DHA was the main constituent in the most active fraction (\#4). The arrow indicates the predicted mass for 9cis RA. As seen from the diagram, no detectable levels of 9cis RA were identified in this fraction.

creased proliferation as determined by BrdU incorporation in either the absence or presence of LG268 (data not shown). Therefore, we conclude that it was the progressive degeneration of DA neurons that was negatively influenced by RXR ligands.

The RXR-ligand-stimulated effect on DA cell number was strikingly potent. Accordingly, SR11237 $(0.1 \mu \mathrm{M})$ was as efficient as glial-cell-line-derived neurotrophic factor (GDNF), a well-established dopaminotrophic factor (Lin et al. 1993), in potentiating the increase in DA cell number, whereas LG268 $(0.1 \mu \mathrm{M})$ was almost twice as potent (Fig. 3C). The concentration of GDNF used in this experiment $(60 \mathrm{ng} / \mathrm{mL})$ was shown to generate optimal survival in parallel dose-response experiments (data not shown). The use of an RXR-specific antagonist, LG1208 (Canan Koch et al. 1996, 1999), together with
LG268 blocked the response, thereby verifying that the effect was due to RXR activation (Fig. 3D). To verify the specificity of LG268 and LG1208 in neuronal cells, primary neuronal cultures were transfected with vectors encoding Gal4-Nurr1 and Gal4-Nurr1 ${ }^{\mathrm{dim}}$ together with a Gal4-responsive luciferase reporter vector. As shown in Figure 3E, LG268 activates Gal4-Nurr1, but not Gal4Nurr ${ }^{\mathrm{dim}}$. As predicted, LG1208 blocks this response. Because Gal4-Nurr1 or Gal4-Nurr1 ${ }^{\mathrm{dim}}$ was transfected without expression vector encoding RXR, these results show that endogenous RXR is available for heterodimerization with transgenic Gal4-Nurrl. In conclusion, these results demonstrate the potential of Nurrl-RXR heterodimers to transduce signaling by RXR ligands in neuronal cells.

Surprisingly, when added alone, the endogenous RXR 
A

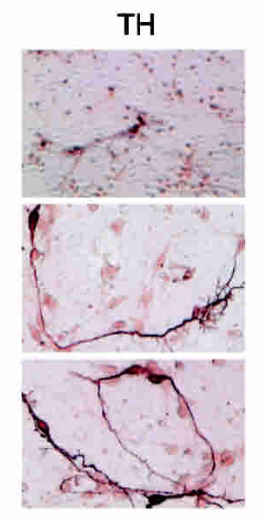

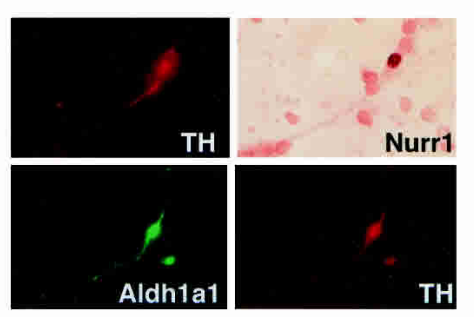

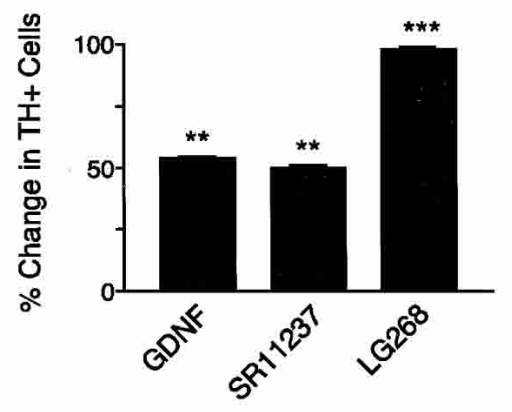

D

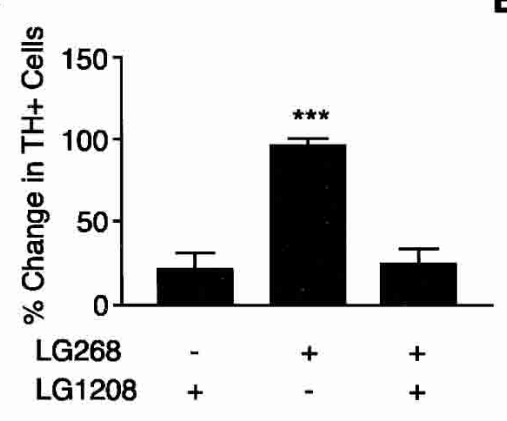

B

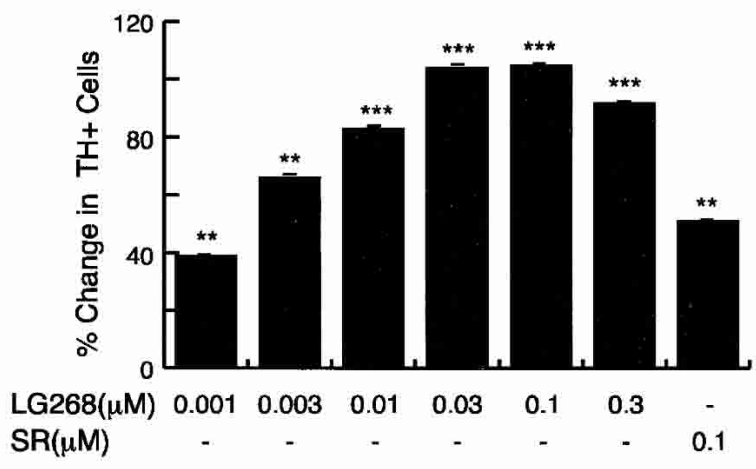

$\mathbf{E}$

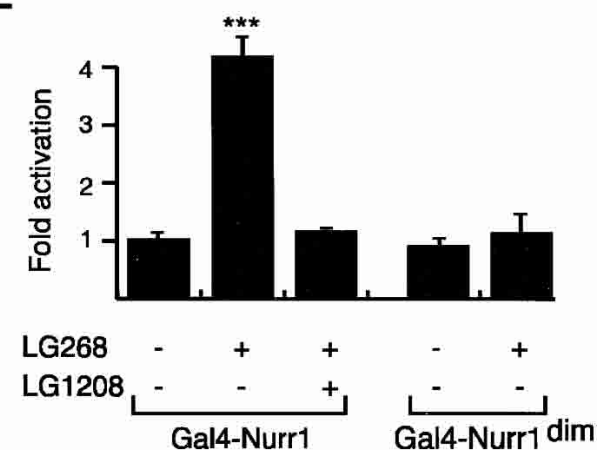

Figure 3. RXR-specific ligands increase the number of surviving DA neurons. Primary cultures from rat ventral midbrain were established at E14.5-E15.5, incubated for 3-5 d in the presence of various ligands, fixed, and stained for DA neuron marker expression. Incubation in N2 media without any addition of ligand was used as control. (A) A few percent of the ventral midbrain cells are DA neurons according to cytoplasmic expression of TH (brightfield; left panel). The TH-positive cells express Nurrl in the nucleus and Aldh1a1 in the cytoplasm. (B) Treatment with LG268 at 0.001-0.3 $\mu \mathrm{M}$ increases the number of TH-positive cells in a dose-dependent manner. Similar treatments with SR11237 also result in an increase in DA neuron number. (C) The effect of SR11237 and LG268 (both at $0.1 \mu \mathrm{M})$ was compared with that of GDNF $(30 \mathrm{ng} / \mathrm{mL})$. (D) Cultures were treated with LG268 alone and in combination with LG1208, an RXR-selective antagonist. Addition of LG1208 blocked the effect of LG268. Treatment of the cultures with LG1208 alone did not have a significant effect on the number of surviving cells. $\left.\left(^{\star \star}\right) p<0.01 ;{ }^{\star \star \star}\right) p<0.001$. $(E)$ To verify the activation potential of LG268 in neuronal cells, primary cultures were transfected with Gal4-Nurr1 and a Gal4-responsive luciferase vector. Values are given as "Fold activation," where 1 is set as the activation obtained with Gal4-Nurrl (or Gal4-Nurr1 ${ }^{\text {dim}) ~ c o t r a n s f e c t e d ~ w i t h ~ t h e ~}$ luciferase reporter but without addition of ligands. Gal4-Nurr1 is activated by LG268, whereas the ligand is unable to activate Gal4-Nurr1 ${ }^{\mathrm{dim}}$ in neuronal cells. The RXR antagonist LG1208 completely abolished activation by LG268.

ligand 9cis RA did not affect the number of surviving DA cells. Given that 9cis RA also activates RAR, this suggested that activation of RAR might negatively influence the ability of RXR ligands to increase DA cell number (Fig. 4A). Two observations corroborated this hypothesis. First, when 9cis RA signaling via RAR was blocked by an RAR-specific antagonist (Ro41-5253; Apfel et al. 1992), a robust increase of surviving DA cells was observed (Fig. 4A). Second, an RAR-specific agonist TTNPB [(E)-4[2-(5,6,7,8-tetrahydro-5,5,8,8-tatramethyl-2-naphtalenyl1) propen-1-yl)]benzoic acid] (Sporn et al. 1984) abolished the increase in surviving DA cells when added together with LG268 (Fig. 4B).

Next, the endogenous RXR-selective ligand DHA was tested in the primary culture assay. Consistent with its ability to activate RXR, treatment with DHA resulted in a strongly increased DA cell number (Fig. 4C; $>200 \%$ increase). Importantly, the RXR-selective antagonist
LG1208 blocked the effect, confirming that the effect of DHA was mediated via activation of RXR (Fig. 4D).

\section{Nurr 1 is essential}

for RXR-ligand-dependent neuroprotection

DA neurons constitute only a minority of total neurons in VMB cultures. To evaluate whether RXR ligands selectively stimulate survival of DA neurons, cells were stained for a general neuronal marker (NeuN) to visualize the entire neuronal population. Notably, RXR-selective ligands did not promote a significant increase in total neuronal number, demonstrating that the increased survival is not general in all neuronal cell types in these cultures (Fig. 5A,B).

As demonstrated above (Fig. 1), endogenous RXR ligands are available at sufficient levels to allow activation of Nurr1-RXR heterodimers in vivo. In addition, as the 
A

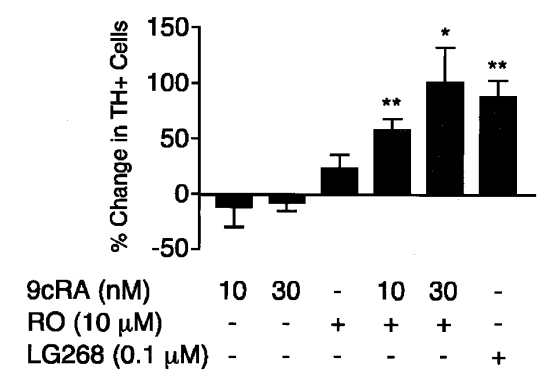

C

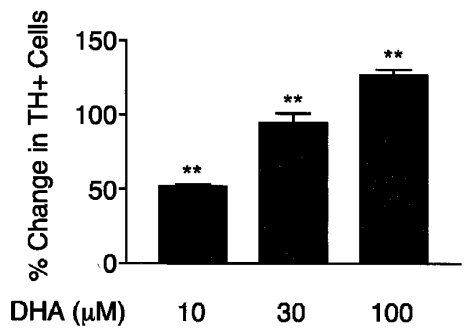

B

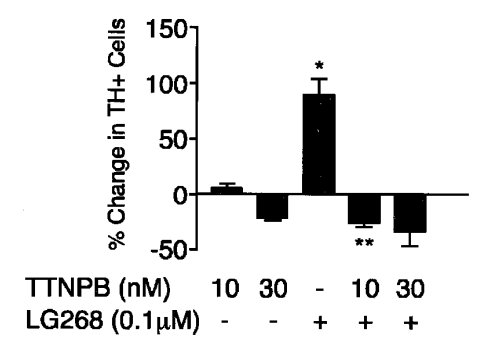

D

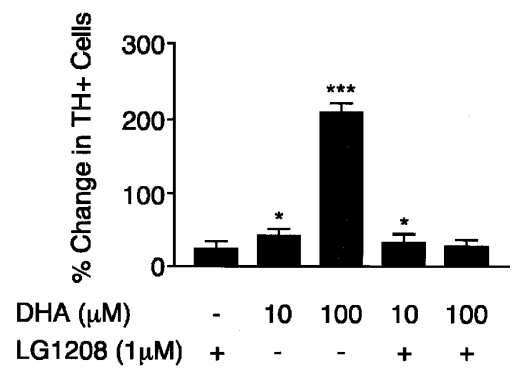

Figure 4. All-trans RA and the low-affinity RXR ligand DHA have opposite effects on DA neuron survival. (A) Treatment of the ventral midbrain primary cultures with 9cis RA did not result in an increase of the number of TH-positive cells (as shown with 10 and $30 \mathrm{nM}$ ). Addition of an RAR-selective antagonist Ro-415253 (RO; $10 \mu \mathrm{M})$ together with 9cis RA leads to a $100 \%$ increase in TH-positive cells. Treatment with RO alone did not increase the number of DA neurons. (B) Treatment of the primary cultures with the RAR-specific agonist TTNPB did not increase DA cell survival (at 10, 30, and $100 \mathrm{nM}$ ). Addition of TTNPB together with LG268 blocked the survival effect seen by addition of LG268 alone. $(C, D)$ Primary midbrain cultures were treated with DHA $(10$, 30 , and $100 \mu \mathrm{M})$. A dose-dependent increase in the number of TH-positive cells was observed. Addition of the RXR antagonist LG1208 $(10 \mu \mathrm{M})$ together with DHA $(10$ and $100 \mu \mathrm{M})$ blocked the effect on cell survival. $\left(^{\star}\right) p<0.05 ;\left(^{\star \star}\right) p<0.01 ;\left(^{\star \star \star}\right)$ $p<0.001$. survival-promoting effect was highly selective for DA neurons, a cell type in which Nurrl is highly expressed, we speculated that Nurrl might be the relevant partner

\section{A}

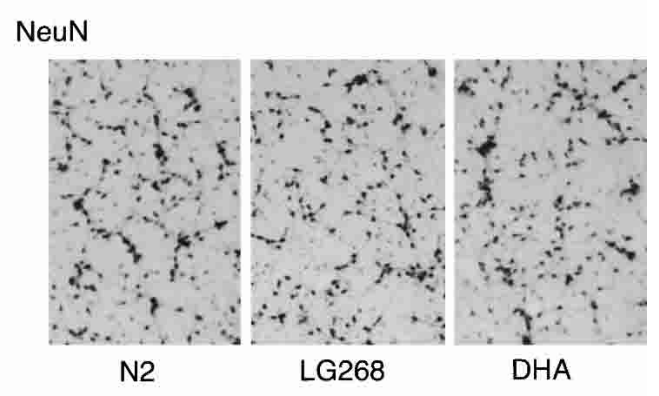

B

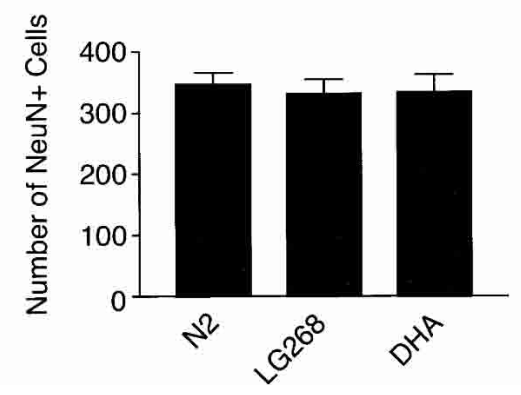

Figure 5. RXR ligands do not cause a general increase in neuronal survival. $(A, B) \mathrm{VMB}$ cultures were treated with $0.1 \mu \mathrm{M}$ LG268 or $60 \mu \mathrm{M}$ DHA, left for $3 \mathrm{~d}$, and then stained for NeuN IR to detect the total neuronal population. LG268 and DHA did not influence the survival of the general neuronal population as no significant changes in the number of neurons were seen by the RXR ligand treatments. of RXR in midbrain DA cells. If this assumption is correct, also non-dopaminergic Nurrl-expressing neurons might respond to RXR ligand. To address this possibility, primary cultures from the developing Nurrl-expressing cortex and hippocampus (Fig. 6A) were treated with LG268. Interestingly, the number of surviving Nurr1positive cells increased in both cortical (Fig. 6B, left graph, $41 \%$ increase) and hippocampal cultures (Fig. 6C, left graph, $49 \%$ increase). A corresponding increase was not observed in Nurr1-negative cells, demonstrating that the survival effect was specific to neurons expressing Nurr1 (Fig. 6B,C, right graphs).

The above experiment indicated a strong correlation between Nurrl expression and the ability to respond to the survival-promoting RXR-ligand-induced effect. The involvement of Nurrl in this process was verified by analyzing neurons from Nurr1-gene-targeted mice. In wild-type rat and mouse cortical primary cultures, a relatively high proportion of neurons are Nurrl-immunoreactive (Fig. 6B,C; data not shown). In line with our hypothesis that Nurrl is essential for the increased survival, LG268 induced a significant increase in total cortical neuronal number in primary cultures from wildtype mice as assessed by NeuN staining (Fig. 6D, left graph), whereas no such increase in NeuN-positive cells was detected in cortical cultures from Nurrl-gene-targeted littermates (Fig. 6D, right graph).

Although the data described above indicate that Nurr 1 is essential for the ability of RXR ligands to promote neuronal survival, it remained possible that the requirement for Nurr1 is indirect. A pharmacological approach was used to address this possibility. Screening of a chemical library resulted in the identification of an aminopyrimidine derivative (XCT0135908; Fig. 7A) that is 
A

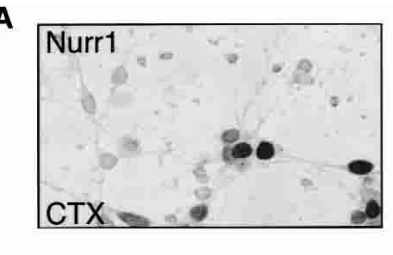

B

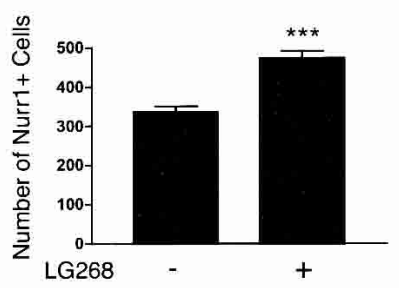

C

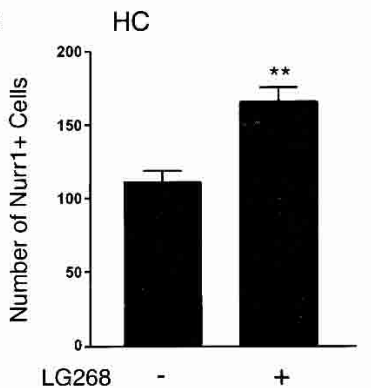

D
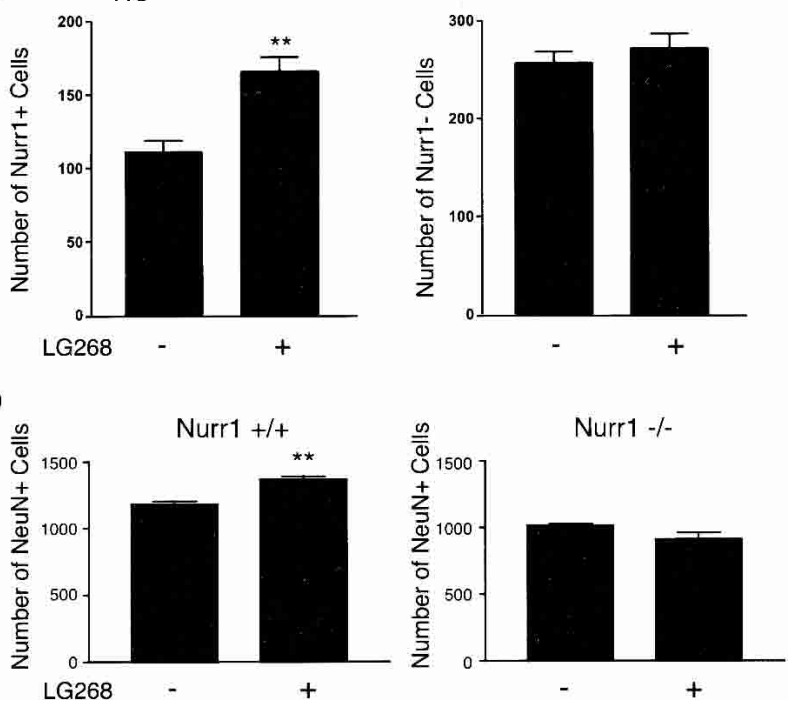

Figure 6. The RXR-dependent survival effect is mediated via Nurr1. E15.5 rat cortex, and hippocampus primary cultures were incubated for $3 \mathrm{~d}$ with or without $0.1 \mu \mathrm{M}$ LG268, fixed, and stained for Nurr1 expression. (A) Brightfield images of cortical (left) and hippocampal (right) cultures analyzed for Nurr1 IR. (B) Approximately one-third of the cells are Nurrl IR in the cortical cultures. In response to treatment with $0.1 \mu \mathrm{M}$ LG268, the number of Nurr1 IR cells increased (left panel), whereas the number of non-Nurr1 IR cells did not (right panel). (C) A similar effect was observed in hippocampal cultures. $(D)$ Cortical cultures were prepared from Nurr1 ${ }^{+/+}$and Nurr1 ${ }^{-/-}$E15.5 embryos and incubated with or without $0.1 \mu \mathrm{M}$ LG268. In cultures from $\mathrm{Nurr}^{+/+}$embryos, the total neuronal population as determined by NeuN expression increased in response to LG268 treatment, but no such increase was observed in cultures from Nurr $1^{-/}$

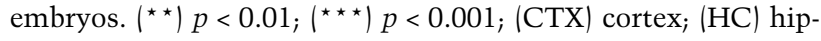
pocampus.

highly selective in activation of heterodimers formed between Gal4-Nurr1 and cotransfected RXR in African green monkey CV-1 cells (Fig. 7A). Notably, at the concentrations used in the experiments $(1 \mu \mathrm{M})$, this compound failed to activate other Gal4-NR derivatives cotransfected with RXR and did not activate RXR alone (Fig. 7A; data not shown). Moreover, activation of Gal4-
Nurr1/RXR was blocked by the addition of an RXR antagonist, indicating that the RXR subunit in these heterodimers is activated by XCT0135908 (data not shown). In line with the results presented above, addition of the Nurr1/RXR-selective compound XCT0135908 to primary cultures from rat VMB increased the number of surviving DA cells whereas nondopaminergic neurons were unaffected (Fig. 7B; data not shown). In transfection experiments in primary neuronal cultures, XCT0135908 activated Gal4-Nurr1 but not Gal4-Nurr1 ${ }^{\text {dim }}$ (Fig. 7C). As predicted, activation of Gal4-Nurr1 was blocked by the RXR antagonist LG1208. Together these data provide additional strong evidence substantiating that Nurrl is an essential heterodimer partner in RXR-ligand-induced neuronal survival.

\section{Discussion}

In its essential function as a silent heterodimerization partner, RXR is at center stage in NR-mediated signaling. However, whether RXR functions as a ligand-binding signaling NR in vivo has remained unclear. Evidence for such a role requires the identification of endogenous RXR ligands that should also be available at sufficient concentrations to allow activation of RXR. Moreover, relevant biological activities influenced by ligand-activated RXR need to be defined. Finally, a central issue concerns the identity of relevant RXR partner(s) in such signaling events. Here we show that RXR ligands are present at several locations in the embryonic CNS, and we demonstrate that they are also available for activation of Nurr1-RXR heterodimers in vivo. Moreover, these data indicate a functional role of RXR ligands in neuroprotection and thus identify a novel Nurr1-dependent signaling pathway of significance in neuronal survival.

\section{Existence of endogenous $R X R$ ligands}

RXR was initially defined as a retinoid receptor based on its ability to become activated and bind 9cis RA (Heyman et al. 1992; Levin et al. 1992). In addition, 9cis RA can also activate RARs. Such dual activation potential would suggest that 9cis RA is essential in vitamin Adependent processes in vivo. Indeed, ligand activation of both subunits in RAR-RXR heterodimers often results in strongly synergistic effects (see, e.g., Roy et al. 1995; Botling et al. 1997; Lu et al. 1997), and previous data have indicated RXR activation in the embryonic spinal cord, likely as a result of 9cis RA ligand binding (Solomin et al. 1998). Moreover, mutations introduced in the ligand-dependent activation function 2 in $\mathrm{RXR} \alpha$ by gene targeting in mice also suggested an active ligand-binding role of $\mathrm{RXR} \alpha$ in retinoid-mediated signaling (Mascrez et al. 1998). However, despite these data, the signaling status of RXR in vivo has been a matter of debate because 9cis RA has been difficult to detect in tissues, and specific isomerases converting atRA into 9cis RA have not been identified (Horton and Maden 1995; Ulven et al. 2001). 
A
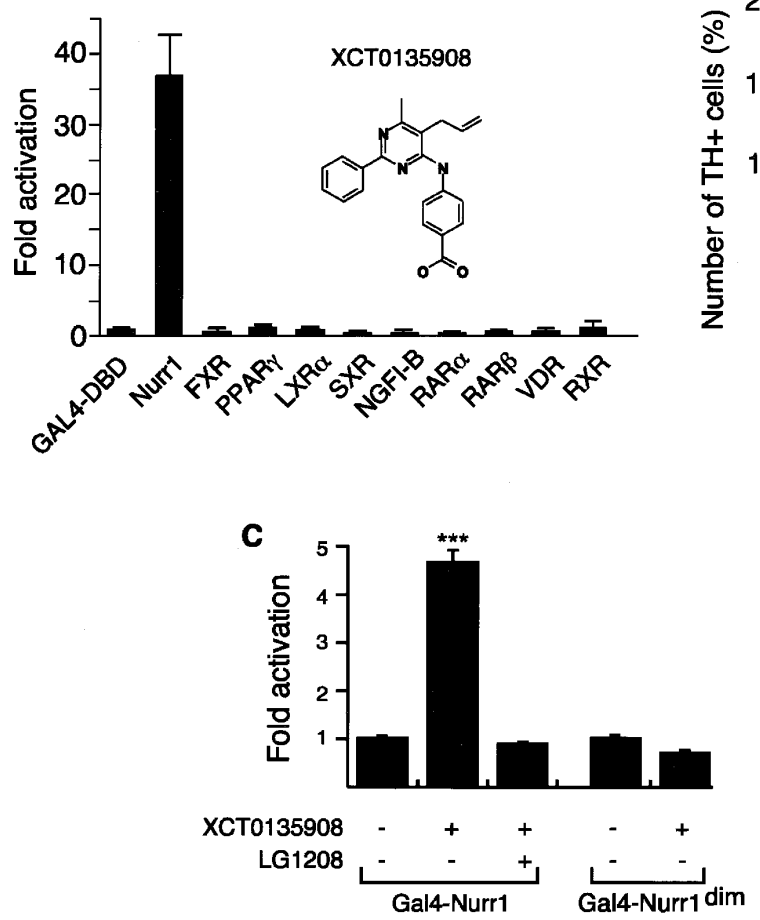

B

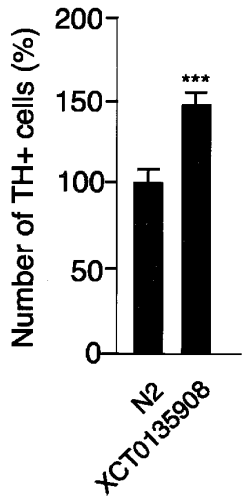

Figure 7. A Nurr1/RXR-selective ligand increases cell survival. (A) In CV-1 cells, several Gal4-NR constructs were cotransfected with RXR. XCT0135908 $(1 \mu \mathrm{M}$; the structure is shown in $A$ ) selectively increased the luciferase activity $\sim 37$-fold when added to cells transfected with the Gal4-Nurr1 and a full-length RXR $\alpha$ expression vectors. Addition of this ligand did not increase the activity in cells transfected with any of the other Gal4NRs, including Gal4-RXR, showing that XCT0135908 is strictly selective for RXR/Nurr1 heterodimers at 1 $\mu \mathrm{M}$. (B) Addition of $1 \mu \mathrm{M}$ XCT0135908 to rat VMB primary cultures increased the number of surviving $\mathrm{TH}$ positive cells by $45 \%$ compared with $\mathrm{N} 2$ media. $\left(^{\star \star \star}\right)$ $p<0.001$. (C) To verify the activation potential of XCT0135908 in neuronal cells, primary cultures were transfected with Gal4-Nurr1 and a Gal4-responsive luciferase vector. Values are given as "Fold activation," where 1 is set as the activation obtained with Gal4Nurr1 (or Gal4-Nurr1 ${ }^{\mathrm{dim}}$ ) cotransfected with luciferase reporter but without addition of ligands. Gal4-Nurr1 is activated by XCT0135908, whereas the ligand is unable to activate Gal4-Nurrl ${ }^{\text {dim }}$ in neuronal cells. The RXR antagonist LG1208 completely abolished activation by XCT0135908.
Thus, 9cis RA may be important at sites containing very high levels of all-trans RA, for example, in the developing embryonic spinal cord, where sufficient amounts of 9 cis RA can be derived from nonenzymatic atRA isomerization.

More recent findings have indicated the existence of endogenous nonretinoid RXR-selective ligands. Phytanic acid is a chlorophyll metabolite activating RXR, but is probably only accumulating at sufficiently high levels to allow activation of RXR in patients with certain metabolic disorders (Kitareewan et al. 1996; Lemotte et al. 1996). The polyunsaturated fatty acid DHA was recently identified as a brain-derived RXR ligand (Mata de Urquiza et al. 2000). Our more recent studies have identified additional RXR-activating fatty acid derivatives in the brain, but also in other tissues (A. Mata de Urquiza and T. Perlmann, unpubl.). These fatty acids are mostly associated with membrane phospholipids, but they can be released in free form and are in several cases highly abundant. Thus, although the exact identity of physiologically relevant endogenous RXR ligands remains to be established, we can conclude that RXR-selective ligands exist in tissues and, as indicated in this study, RXR is apparently ligand activated in the embryonic CNS. As demonstrated by partial purification, one of the active components of E15.5 midbrain tissue was indeed identified as DHA (Fig. 2F).

\section{Nurr1 as a silent partner in Nurr1-RXR heterodimers}

This study defines a new role of Nurrl in RXR-ligandmediated signaling in neurons. Evidence for the involve- ment of Nurr1 in RXR-ligand-dependent signaling is derived from several observations: (1) Nurrl-expressing cells, but not other neurons in the $\mathrm{VMB}$, cortex, and hippocampus respond to RXR ligand treatment. (2) Cells cultured from the cortex of Nurrl-gene-targeted mice fail to respond to RXR ligand treatment. (3) A synthetic compound (XCT0135908) selectively activating Nurr1RXR heterodimers stimulated DA neuron survival. (4) Nurr1-RXR heterodimers can be activated in vivo, apparently as a result of RXR ligand binding, as demonstrated in our transgenic mouse experiments. Together, these observations provide compelling evidence showing that Nurr1-RXR heterodimers are responsible for transducing the neuroprotective effect.

Nurrl can also bind to DNA either as monomers or homodimers, and it seems likely that both RXR-dependent and -independent activities are essential for Nurr1 functions in vivo. For example, although previous data indicated that Nurr1 functions independently of RXR at early stages of DA cell development (Castro et al. 2001), the RXR-dependent survival-promoting effect presented here may be more relevant at later stages of brain maturation and in the postnatal brain. Such effects will remain undetected in Nurr1-null-gene-targeted mice, as these die immediately after birth (Zetterström et al. 1997; Castillo et al. 1998; Saucedo-Cardenas et al. 1998).

Nurr1 belongs to an evolutionarily conserved subgroup of NRs that can bind DNA as monomers, homodimers, and heterodimers with RXR. Despite intense efforts, neither synthetic nor natural compounds that can modulate the activity of Nurrl in an apparent liganddependent manner have been identified. The recently de- 
scribed X-ray crystal structure of the LBDs of Nurr1 and its Drosophila homolog DHR38 have explained the reason for these difficulties (Baker et al. 2003; Wang et al. 2003). Accordingly, although the Nurr1 LBD largely resembles LBDs of other NRs, it lacks a cavity for ligand binding, thus defining Nurr1 as a ligand-independent orphan NR. This remarkable property distinguishes Nurrl (and most likely NGFI-B) from other RXR heterodimer partners, which all have identified ligands. We speculate that an important ligand-independent function of Nurr1 is to function as a silent partner of RXR and thereby indirectly promote ligand-mediated signaling in vivo. Curiously, in such a mechanism Nurrl resembles the function of RXR in other heterodimers.

\section{Nurr1 in neuroprotection}

The results presented here demonstrate that Nurrl has a survival-promoting function in Nurrl-expressing neurons. Previous studies have provided suggestive evidence for a neuroprotective role of Nurrl in mature DA neurons. Compared with DA neurons derived from wildtype animals, these cells are more vulnerable in Nurr1gene-targeted heterozygous mice (Le et al. 1999b; Eells et al. 2002; Le et al. 2003). In addition, recent genetic analyses in familial Parkinson's patients underscored the importance of Nurrl for the maintenance of dopaminergic cells in the human brain (Le et al. 2003). It is important to emphasize, however, that the results presented here implicate Nurrl and RXR in a more versatile neuroprotective function, as not only midbrain DA cells, but also Nurr1-expressing neurons in the cortex and hippocampus respond to RXR ligand treatment. Given the ubiquitous expression of RXR (Mangelsdorf et al. 1992; Dolle et al. 1994; Zetterström et al. 1999), Nurr1 availability may thus determine the responsiveness of neurons to RXRligand-promoted survival. Nurrl is encoded by an immediate early gene that is rapidly induced by various stressful insults including ischemia, and it is interesting to speculate that such up-regulation in response to stressful insults reflects a cytoprotective mechanism mediated by Nurr1-RXR heterodimers (Law et al. 1992; Crispino et al. 1998; Honkaniemi and Sharp 1999).

\section{Endogenous RXR ligands in neuroprotection}

Are endogenous RXR ligands neuroprotective in vivo? The apparent accumulation of RXR ligand activity during development and in the postnatal brain seems consistent with a functional role in maintenance of developing and mature neurons. Ligands that are biologically relevant in such a neuronal survival pathway should be selective for RXR, because RAR ligands, including the RAR/RXR ligand 9cis RA, inhibit RXR-ligand-mediated neuronal survival (Fig. 4). Notably, although their exact biochemical nature remains to be determined, the endogenous ligand activities defined here fulfill this criterion because they are specific for RXR and pharmacologically distinct from 9cis RA. It should be noted, however, that definitive evidence for a role of RXR and endogenous RXR ligands in the adult brain remains to be provided.

A previously identified ligand that may contribute to activation of Nurrl-RXR heterodimers in vivo is the polyunsaturated fatty acid DHA. Of note, DHA has in previous studies been shown to be neuroprotective (Glozman et al. 1998; Lauritzen et al. 2000; Politi et al. 2001), and we demonstrate here that DHA has a robust ability to increase the survival of DA neurons. An RXR antagonist blocked this effect, supporting the hypothesis that DHA can be neuroprotective via activation of RXR. DHA is mainly associated with membrane phospholipids. However, it can be released as free acid, for example, upon stressful insults such as ischemia (Neuringer et al. 1988; Baker and Chang 1992). Because Nurr1 is encoded by an immediate early gene, it is intriguing to speculate that both Nurr1 and endogenous RXR ligands are made available under situations requiring engagement by acutely induced neuroprotective mechanisms.

\section{$R X R$ as a target for treatment} of neurodegenerative disease

NRs have major potential as drug targets. However, whereas several metabolic disorders are clearly amenable to NR ligand treatment (eg., via activation of PPAR $\gamma$ ), much less progress has been made in understanding NR functions of potential relevance in neurological disorders. The results presented here suggest that RXR ligand administration may provide a novel approach in treatment of neurodegenerative disease. The high levels of Nurrl expression in DA neurons and in cortical and hippocampal neurons in response to hypoxic stress (Honkaniemi and Sharp 1996) suggest that both Parkinson's disease and stroke may be relevant disorders in further studies toward this goal. RXR's versatile role as a common heterodimer partner might increase the risk for unwanted side effects and is a concern in any pharmacological approach involving RXR agonists. The unique pharmacological properties of the Nurr1-RXRspecific agonist XCT0135908 are therefore intriguing and warrant further in vitro and in vivo studies in models of neurodegenerative disease.

\section{Materials and methods}

Tissue explants and conditioned medium

NMRI mouse embryo midbrains were dissected (dissection microscope SMZ-2T; Nikon) and either placed directly on transfected JEG3 cells or fine-dissected into separate ventral and dorsal pieces and placed on the cells. The tissue was weighed to get equal amounts of tissue on the cells. For generation of tissueconditioned medium, tissue was excised, cut into small pieces, and placed in serum-free minimal essential medium (MEM; GIBCO). Incubation in cell culture incubator was overnight, followed by centrifugation and removal of tissue. This conditioned medium was placed on transfected cells. 


\section{Tissue culture and transfections}

Human choriocarcinoma JEG3 cells were transfected in triplicates with 100 ng of receptor CMX-Gal4-Nurr1, CMX-Gal4Nurr $^{\text {dim }}$ (point mutation in LBD I-box P560A), $\pm 100 \mathrm{ng}$ of CMX-RXR and $100 \mathrm{ng}$ of Gal4-binding luciferase reporter MH100-tk-luc using the calcium phosphate method (Perlmann et al. 1993). In the experiment with conditioned media and titration of 9cis RA, CMX-Gal4-RAR was also used. In all experiments, CMX- $\beta$-Gal (200 ng) was used as an internal control. Calcium precipitate was removed by rinses $6 \mathrm{~h}$ posttransfection, and relevant substances were added to cells. After $24 \mathrm{~h}$, cells were harvested and assayed for luciferase and reference $\beta$-galactosidase activity on a luminometer/photometer reader (Lucy-1; Anthos).

CV-1 cells were cultured in DMEM (Sigma) with $10 \%$ charcoal stripped FCS (HyClone), $50 \mu \mathrm{g} / \mathrm{mL}$ Gentamycin (GIBCO, Invitrogen), and plated at 10,000 cells/well in DMEM with 5\% charcoal stripped FCS (HyClone) and $50 \mu \mathrm{g} / \mathrm{mL}$ Gentamycin into 96-well plates $1 \mathrm{~d}$ previous to transfecting. Transfections were carried out using FuGENE6 reagent (Roche). Briefly, $70 \mathrm{ng}$ of DNA was transfected per well with $0.25 \mu \mathrm{L}$ of FuGENE6 reagent. For heterodimer selectivity assays, 20 ng of $\mathrm{MH100x4-}$ tk-luciferase, $20 \mathrm{ng}$ of the appropriate CMX-GAL4-LBD construct, $20 \mathrm{ng}$ of CMX-RXR-LBD, and $10 \mathrm{ng}$ of CMX- $\beta-\mathrm{Gal}$, were transfected. The compound was added $5 \mathrm{~h}$ after transfection at the concentrations indicated in the figure, and the transfection was assayed $18 \mathrm{~h}$ later unless otherwise indicated. Cells were lysed, and the luciferase activity was measured using an LJL Analyst plate reader and normalized to $\beta$-galactosidase activity. All experiments were carried out a minimum of three times.

Partial purification of tissue factor from brain-conditioned medium

Embryonal conditioned medium was prepared using forebrain tissue from 80 mouse embryos (E15.5) as described above. Medium was extracted using hexane as described (Mata de Urquiza et al. 2000), reconstituted in a minimum of HPLC-mobile phase (methanol:isopropanol:water, 80:10:10 [v/v], with $0.5 \%$ acetic acid) and fractionated using an isocratic gradient $(0.2 \mathrm{~mL} / \mathrm{min})$ on a reverse-phase C18-column (ACE, $250 \times 2.1 \mathrm{~mm}$, Advanced Chromatography Technologies). Fractions were reconstituted in ethanol and tested for activity by adding small aliquots to HEK293 cells transfected with effector and reporter plasmids (Mata de Urquiza et al. 2000). Active fractions were analyzed by negative ion electrospray mass spectrometry using a Quattro Micro triple-quadrupole mass spectrometer (Micromass).

\section{Gal4-transgenic mice}

The bicistronic UAS-hsp-gRAR/lacZ construct (Mata De Urquiza et al. 1999) was cleaved with XhoI and NheI to replace part of the Gal4 (g) and entire RAR-LBD cDNA with the corresponding Gal4 sequence and LBD cDNA from CMX-gNurr1 and CMX-gNurr ${ }^{\text {dim }}$ LBDs, respectively. Constructs purified from vector sequences (Not1 cleavage) were microinjected into pronuclei of fertilized eggs from matings of C57BL/6xCBA hybrid mice. For the Gal4-Nurr1 wild type, seven founder lines were established and mated to wild-type mice for generation of offspring for embryonic analyses. In addition, transient transgenic embryos were generated. For Gal4-Nurr ${ }^{\mathrm{dim}}$, transient transgenic embryos only were used. In total, 19 Gal4-Nurrl and 17 Gal4- Nurr $1^{\text {dim }}$ mouse lines were obtained. Embryos were dissected at E11.5, fixed for $30 \mathrm{~min}$ in $0.2 \%$ glutaraldehyde, followed by immersion in X-gal staining solution $\left(2 \mathrm{mM} \mathrm{MgCl}{ }_{2}\right.$, $0.02 \%$ NP-40, $0.01 \%$ Na-deoxycholate, $5 \mathrm{mM} \mathrm{K}_{4} \mathrm{Fe}[\mathrm{CN}]_{6}, 5 \mathrm{mM}$ $\mathrm{K}_{3} \mathrm{Fe}[\mathrm{CN}]_{6}$, and $1 \mathrm{mg} / \mathrm{mL}$ X-gal [5-bromo-4-chloro-3-indoyl- $\beta$ - $\mathrm{D}$ - galactopyranoside]) overnight at $37^{\circ} \mathrm{C}$. Embryos were rinsed in PBS and postfixed in $4 \%$ paraformaldehyde. Amnion-derived DNA was used for genotyping.

Nurr1-gene-targeted mice

Generation and genotyping of Nurr1 mutant mice was described previously (Zetterström et al. 1997).

\section{Histology}

Coronal cryosections of Gal4-Nurr1 embryos were prepared at $14 \mu \mathrm{m}$ thickness.

\section{In situ hybridization histochemistry}

For Nurr1 mRNA analysis, the protocol previously described was used (Wallén et al. 1999).

\section{Immunofluorescent histochemistry}

TH (1:200; Pel-Freez) and Aldh1a1 (1:400; generous gift from R. Lindahl, University of South Dakota, Vermillion) primary antiserum was diluted in PBS with $0.3 \%$ Triton X-100 and $0.5 \%$ fetal calf serum and incubated on paraformaldehyde-fixed sections overnight at $4^{\circ} \mathrm{C}$, followed by rinses in PBS and immunodetection by Cy3-conjugated IgG (Jackson ImmunoResearch).

\section{Primary cultures}

$\mathrm{VMB}$, hippocampus, and cortex from rat $(\mathrm{B} \& \mathrm{~K})$ and mouse (Zetterström et al. 1997) embryos at stage E14.5-E15.5 were dissected, mechanically dissociated, and plated on poly-D-lysinecoated 12- or 24-well plates in serum-free medium (N2) consisting of a 1:1 mixture of MEM (GIBCO) with $15 \mathrm{mM}$ HEPES buffer (GIBCO) and Ham's F12 medium (GIBCO). The mixture was supplemented with $6 \mathrm{mg} / \mathrm{mL}$ glucose, $1 \mathrm{mg} / \mathrm{mL}$ bovine serum albumin, $5 \mu \mathrm{g} / \mathrm{mL}$ insulin, $100 \mu \mathrm{g} / \mathrm{mL}$ transferrin, $60 \mu \mathrm{M} \mathrm{pu}-$ trescine, $20 \mathrm{nM}$ progesterone, $30 \mathrm{nM}$ selenium, and $1 \mathrm{mM}$ glutamine (Sigma). Ligands included stock solutions in DMSO; 9cis RA (Sigma); LG100268, LG100849, and LG1001208 (kindly provided by Mark Leibowitz at Ligand Pharmaceuticals); (E)-4-[2-(5,6,7,8-tetrahydro-5,5,8,8-tetramethyl-2-naphthalenyl)-1propenyl]benzoic acid (TTNPB), DHA (Sigma), GDNF (SigmaAldrich), SR11237 (Roche), and Ro41-5253 (kindly provided by Louise Foley at Hoffman-LaRoche). These were diluted to working concentrations in N2 and added to cells in triplicates. Cells were incubated 3-5 d. Paraformaldehyde-fixed cultures were incubated overnight with TH (1:1000; Pel-Freez), NeuN (1:200; Chemicon), or Nurr1 (1:10.000; Santa Cruz Biotechnology) antiserum in PBS containing 0.5\% (TH and NeuN) or $10 \%$ (Nurr1) fetal calf serum and $0.3 \%$ Triton X-100. Following rinses, cultures were incubated with biotinylated secondary antibody followed by detection of immunostaining using the ABC immunoperoxidase kit from Vector. Cortical primary neurons were transfected using the Nucleofector technology and the Rat Neuron Nucleofector kit (Amaxa biosystems Gmbh) according to the manufacturer's protocol. A total of $1.5 \mu \mathrm{g}$ of CMX-Gal4Nurr1 or CMX-Gal4-Nurr1 ${ }^{\mathrm{dim}}, \pm 1.5 \mu \mathrm{g}$ of CMX-RXR and $1 \mu \mathrm{g}$ of MH100-tk-luc and $0.5 \mu \mathrm{g}$ of CMX- $\beta$-Gal were added per $6 \times 10^{6}$ cells; $1 \times 10^{6}$ cells were plated per $2-\mathrm{cm}^{2}$ well. Ligands were added within $4 \mathrm{~h}$ after plating. Cells were lysed after 18-20 h and assayed for luciferase and reference $\beta$-galactosidase activity as described above.

\section{Microscopical analysis and image collection}

Analysis, imaging, and cell counting were performed on Eclipse E1000M and Eclipse TE300 microscopes (both Nikon) coupled to the Spot2 camera (Diagnostic Instruments). To obtain unbi- 
ased results, counts were made by two persons. Statistical analyses were by Student's $t$-test.

\section{Acknowledgments}

We thank the CMB mouse camp at Karolinska Institutet for generating the transgenic animals used in this study. Gérard Benoit, Michal Malewicz, Ola Hermanson, and Urban Lendahl are acknowledged for their comments on this manuscript. This study was supported by the Göran Gustafsson Foundation and the Swedish Foundation for Strategic Research.

The publication costs of this article were defrayed in part by payment of page charges. This article must therefore be hereby marked "advertisement" in accordance with 18 USC section 1734 solely to indicate this fact.

\section{References}

Aarnisalo, P., Kim, C.H., Lee, J.W., and Perlmann, T. 2002. Defining requirements for heterodimerization between the retinoid X receptor and the orphan nuclear receptor Nurr1. I. Biol. Chem. 277: 35118-35123.

Apfel, C., Bauer, M., Crettaz, M., Forni, L., Kamber, M., Kaufman, F., LeMotte, P., Pirson, W., and Klaus, M. 1992. A retinoic acid receptor $\alpha$ antagonist selectively counteracts retinoic acid effects. Proc. Natl. Acad. Sci. 89: 7129-7133.

Aranda, A. and Pascual, A. 2001. Nuclear hormone receptors and gene expression. Physiol. Rev. 81: 1269-1304.

Baker, R.R. and Chang, H.Y. 1992. The hydrolysis of natural phosphatidylethanolamines by phospholipase A2 from rat serum: A degree of selectivity is shown for docosahexaenoate release. Biochim. Biophys. Acta 1125: 56-61.

Baker, K.D., Shewchuk, L.M., Kozlova, T., Makishima, M., Hassell, A., Wisely, B., Caravella, J.A., Lambert, M.H., Reinking, J.L., Krause, H., et al. 2003. The Drosophila orphan nuclear receptor DHR38 mediates an atypical ecdysteroid signaling pathway. Cell 113: 731-742.

Boehm, M.F., Zhang, L., Zhi, L., McClurg, M.R., Berger, E., Wagoner, M., Mais, D.E., Suto, C.M., Davies, P.J.A., Heyman, R.A., et al. 1995. Design and synthesis of potent retinoid X receptor selective ligands that induce apoptosis in leukemia cells. J. Med. Chem. 38: 3146-3155.

Botling, J., Castro, D.S., Oberg, F., Nilsson, K., and Perlmann, T. 1997. Retinoic acid receptor/retinoid X receptor heterodimers can be activated through both subunits providing a basis for synergistic transactivation and cellular differentiation. J. Biol. Chem. 272: 9443-9449.

Branton, R.L. and Clarke, D.J. 1999. Apoptosis in primary cultures of E14 rat ventral mesencephala: Time course of dopaminergic cell death and implications for neural transplantation. Exp. Neurol. 160: 88-98.

Canan Koch, S.S., Dardashti, L.J., Hebert, J.J., White, S.K., Croston, G.E., Flatten, K.S., Heyman, R.A., and Nadzan, A.M. 1996. Identification of the first retinoid X receptor homodimer antagonist. J. Med. Chem. 39: 3229-3234.

Canan Koch, S.S., Dardashti, L.J., Cesario, R.M., Croston, G.E., Boehm, M.F., Heyman, R.A., and Nadzan, A.M. 1999. Synthesis of retinoid $X$ receptor-specific ligands that are potent inducers of adipogenesis in 3T3-L1 cells. J. Med. Chem. 42: 742-750.

Castillo, S.O., Baffi, J.S., Palkovits, M., Goldstein, D.S., Kopin, I.J., Witta, J., Magnuson, M.A., and Nikodem, V.M. 1998. Dopamine biosynthesis is selectively abolished in substantia nigra/ventral tegmental area but not in hypothalamic neurons in mice with targeted disruption of the Nurr1 gene. Mol. Cell. Neurosci. 11: 36-46.
Castro, D.S., Hermanson, E., Joseph, B., Wallen, A., Aarnisalo, P., Heller, A., and Perlmann, T. 2001. Induction of cell cycle arrest and morphological differentiation by Nurr1 and retinoids in dopamine MN9D cells. J. Biol. Chem. 276: 4327743284.

Crispino, M., Tocco, G., Feldman, J.D., Herschman, H.R., and Baudry, M. 1998. Nurrl mRNA expression in neonatal and adult rat brain following kainic acid-induced seizure activity. Brain Res. Mol. Brain Res. 59: 178-188.

Dolle, P., Fraulob, V., Kastner, P., and Chambon, P. 1994. Developmental expression of murine retinoid $\mathrm{X}$ receptor (RXR) genes. Mech. Dev. 45: 91-104.

Eells, J.B., Yeung, S.K., and Nikodem, V.M. 2002. Dopamine neurons heterozygous for the Nurr1-null allele have reduced survival in vitro. Neurosci. Res. Comm. 30: 173-183.

Forman, B.M., Umesono, K., Chen, J., and Evans, R.M. 1995. Unique response pathways are established by allosteric interactions among nuclear hormone receptors. Cell 81: 541550.

Germain, P., Iyer, J., Zechel, C., and Gronemeyer, H. 2002. Coregulator recruitment and the mechanism of retinoic acid receptor synergy. Nature 415: 187-192.

Giguère, V. 1999. Orphan nuclear receptors: From gene to function. Endocr. Rev. 20: 689-725.

Glozman, S., Green, P., and Yavin, E. 1998. Intraamniotic ethyl docosahexaenoate administration protects fetal rat brain from ischemic stress. J. Neurochem. 70: 2484-2491.

Heyman, R.A., Mangelsdorf, D.J., Dyck, J.A., Stein, R.B., Eichele, G., Evans, R.M., and Thaller, C. 1992. 9-cis retinoic acid is a high affinity ligand for the retinoid $\mathrm{X}$ receptor. Cell 68: $397-406$.

Honkaniemi, J. and Sharp, F.R. 1996. Global ischemia induces immediate-early genes encoding zinc finger transcription factors. J. Cereb. Blood Flow Metab. 16: 557-565.

- 1999. Prolonged expression of zinc finger immediateearly gene mRNAs and decreased protein synthesis following kainic acid induced seizures. Eur. J. Neurosci. 11: 10-17.

Horton, C. and Maden, M. 1995. Endogenous distribution of retinoids during normal development and teratogenesis in the mouse embryo. Dev. Dyn. 202: 312-323.

Hyman, C., Hofer, M., Barde, Y.A., Yuhasz, M., Yancopoulos, G.D., Squinto, S.P., and Lindsay, R.M. 1991. BDNF is a neurotrophic factor for dopaminergic neurons of the substantia nigra. Nature 350: 230-232.

Hynes, M. and Rosenthal, A. 1999. Specification of dopaminergic and serotonergic neurons in the vertebrate CNS. Curr. Op. Neurobiol. 9: 26-36.

Johansson, I.M., Wester, P., Hakova, M., Gu, W., Seckl, J.R., and Olsson, T. 2000. Early and delayed induction of immediate early gene expression in a novel focal cerebral ischemia model in the rat. Eur. J. Neurosci. 12: 3615-3625.

Kitareewan, S., Burka, L.T., Tomer, K.B., Parker, C.E., Deterding, L.J., Stevens, R.D., Forman, B.M., Mais, D.E., Heyman, R.A., McMorris, T., et al. 1996. Phytol metabolites are circulating dietary factors that activate the nuclear receptor RXR. Mol. Biol. Cell 7: 1153-1166.

Lauritzen, I., Blondeau, N., Heurteaux, C., Widmann, C., Romey, G., and Lazdunski, M. 2000. Polyunsaturated fatty acids are potent neuroprotectors. EMBO J. 19: 1784-1793.

Law, S.W., Conneely, O.M., DeMayo, F.J., and O'Malley, B.W. 1992. Identification of a new brain-specific transcription factor, NURR1. Mol. Endocrinol. 6: 2129-2135.

Le, W., Conneely, O.M., Zou, L., He, Y., Saucedo-Cardenas, O., Jankovic, J., Mosier, D.R., and Appel, S.H. 1999a. Selective agenesis of mesencephalic dopaminergic neurons in Nurr1deficient mice. Exp. Neurol. 159: 451-458. 
Le, W.-D., Conneely, O.M., He, Y., Jankovic, J., and Appel, S.H. 1999b. Reduced Nurr1 expression increases the vulnerability of mesencephalic dopamine neurons to MPTP-induced injury. J. Neurochem. 73: 2218-2221.

Le, W.D., Xu, P., Jankovic, J., Jiang, H., Appel, S.H., Smith, R.G., and Vassilatis, D.K. 2003. Mutations in NR4A2 associated with familial Parkinson disease. Nat. Genet. 3: 385-389.

Lehmann, J.M., Jong, L., Fanjul, A., Cameron, J.F., Lu, X.P., Haefner, P., Dawson, I., and Pfahl, M. 1992. Retinoids selective for retinoid $\mathrm{X}$ receptor response pathways. Science 258: $1944-1946$.

Lemotte, P.K., Keidel, S., and Apfel, C.M. 1996. Phytanic acid is a retinoid X receptor ligand. Eur. J. Biochem. 236: 328-333.

Levin, A.A., Sturzenbecker, L.J., Kazmer, S., Bosakowski, T., Huselton, C., Allenby, G., Speck, J., Kratzeisen, C., Rosenberger, M., Lovey, A., et al. 1992. 9-cis retinoic acid steroisomer binds and activates the nuclear receptor RXR $\alpha . \mathrm{Na}$ ture 355: 359-361.

Lin, L.F., Doherty, D.H., Lile, J.D., Bektesh, S., and Collins, F. 1993. GDNF: A glial cell line-derived neurotrophic factor for midbrain dopaminergic neurons. Science 260: 1130-1132.

Lin, T.N., Chen, J.J., Wang, S.J., Cheng, J.T., Chi, S.I., Shyu, A.B., Sun, G.Y., and Hsu, C.Y. 1996. Expression of NGFI-B mRNA in a rat focal cerebral ischemia-reperfusion model. Brain Res. Mol. Brain Res. 43: 149-156.

Lu, H.C., Eichele, G., and Thaller, C. 1997. Ligand-bound RXR can mediate retinoid signal transduction during embryogenesis. Development 124: 195-203.

Mangelsdorf, D.J. and Evans, R.M. 1995. The RXR heterodimers and orphan receptors. Cell 83: 841-850.

Mangelsdorf, D.J., Ong, E.S., Dyck, J.A., and Evans, R.M. 1990. Nuclear receptor that identifies a novel retinoic acid response pathway. Nature 345: 224-229.

Mangelsdorf, D.J., Borgmeyer, U., Heyman, R.A., Zhou, J.Y., Ong, E.S., Oro, A.E., Kakizuka, A., and Evans, R.M. 1992. Characterization of three RXR genes that mediate the action of 9-cis retinoic acid. Genes \& Dev. 6: 329-344.

Mascrez, B., Mark, M., Dierich, A., Ghyselinck, N.B., Kastner, P., and Chambon, P. 1998. The RXR $\alpha$ ligand-dependent activation function 2 (AF-2) is important for mouse development. Development 125: 4691-4707.

Mata de Urquiza, A., Solomin, L., and Perlmann, T. 1999. Feedback-inducible nuclear-receptor-driven reporter gene expression in transgenic mice. Proc. Natl. Acad. Sci. 96: 1327013275.

Mata de Urquiza, A., Liu, S., Sjöberg, M., Zetterström, R.H., Griffiths, W., Sjövall, J., and Perlmann, T. 2000. Docosahexaenoic acid: A ligand for the retinoid $\mathrm{X}$ receptor in the mouse brain. Science 290: 2140-2144.

Neumann-Haefelin, T., Wiessner, C., Vogel, P., Back, T., and Hossmann, K.A. 1994. Differential expression of the immediate early genes c-fos, c-jun, junB, and NGFI-B in the rat brain following transient forebrain ischemia. J. Cereb. Blood Flow Metab. 14: 206-216.

Neuringer, M., Anderson, G.J., and Connor, W.E. 1988. The essentiality of $\mathrm{n}-3$ fatty acids for the development and function of the retina and brain. Annu. Rev. Nutr. 8: 517-541.

Perlmann, T. and Jansson, L. 1995. A novel pathway for vitamin A signaling mediated by RXR heterodimerization with NGFI-B and NURR1. Genes \& Dev. 9: 769-782.

Perlmann, T., Rangarajan, P.N., Umesono, K., and Evans, R.M. 1993. Determinants for selective RAR and TR recognition of direct repeat HREs. Genes \& Dev. 7: 1411-1422.

Philips, A., Lesage, S., Gingras, R., Maira, M.H., Gauthier, Y., Hugo, P., and Drouin, J. 1997. Novel dimeric Nur77 signaling mechanism in endocrine and lymphoid cells. Mol. Cell.
Biol. 17: 5946-5951.

Politi, L.E., Rotstein, N.P., and Carri, N.G. 2001. Effect of GDNF on neuroblast proliferation and photoreceptor survival: Additive protection with docosahexaenoic acid. Invest. Ophthalmol. Vis. Sci. 42: 3008-3015.

Repa, J.J., Turley, S.D., Lobaccaro, J.-M.A., Medina, J., Li, L., Lustig, K., Shan, B., Heyman, R.A., Dietschy, J.M., and Mangelsdorf, D.J. 2000. Regulation of absorption and ABC1-mediated efflux of cholesterol by RXR heterodimers. Science 289: 1524-1529.

Roy, B., Taneja, R., and Chambon, P. 1995. Synergistic activation of retinoic acid (RA)-responsive genes and induction of embryonic carcinoma cell differentiation by an RA receptor $\alpha(\operatorname{RAR} \alpha)^{-}, \operatorname{RAR} \beta$-, or RAR $\gamma$-selective ligands in combination with a retinoid $\mathrm{X}$ receptor-selective ligand. Mol. Cell. Biol. 15: 6481-6487.

Saucedo-Cardenas, O., Quintana-Hau, J.D., Le, W.D., Smidt, M.P., Cox, J.J., De Mayo, F., Burbach, J.P., and Conneely, O.M. 1998. Nurr1 is essential for the induction of the dopaminergic phenotype and the survival of ventral mesencephalic late dopaminergic precursor neurons. Proc. Natl. Acad. Sci. 95: 4013-4018.

Sockanathan, S. and Jessell, T.M. 1998. Motor neuron-derived retinoid signaling specifies the subtype identity of spinal motor neurons. Cell 94: 503-514.

Solomin, L., Johansson, C.B., Zetterstrom, R.H., Bissonnette, R.P., Heyman, R.A., Olson, L., Lendahl, U., Frisen, J., and Perlmann, T. 1998. Retinoid-X receptor signalling in the developing spinal cord. Nature 395: 398-402.

Sporn, M.B., Roberts, A.B., and Goodman, D.S. 1984. The retinoids. Academic Press, New York.

Ulven, S.M., Gundersen, T.E., Sakhi, A.K., Glover, J.C., and Blomhoff, R. 2001. Quantitative axial profiles of retinoic acid in the embryonic mouse spinal cord: 9-cis retinoic acid only detected after all-trans-retinoic acid levels are superelevated experimentally. Dev. Dyn. 222: 341-353.

Wallén, A., Zetterstrom, R.H., Solomin, L., Arvidsson, M., Olson, L., and Perlmann, T. 1999. Fate of mesencephalic AHD2-expressing dopamine progenitor cells in NURR1 mutant mice. Exp. Cell Res. 253: 737-746.

Wang, Z., Benoit, G., Liu, J., Prasad, S., Aarnisalo, P., Liu, X., Xu, H., Walker, N.P.C., and Perlmann, T. 2003. Structure and function of Nurr1 identifies a class of ligand-independent nuclear receptors. Nature 423: 555-560.

Wilson, T.E., Fahrner, T.J., and Milbrandt, J. 1993. The orphan receptors NGFI-B and steroidogenic factor 1 establish monomer binding as a third paradigm of nuclear receptor-DNA interaction. Mol. Cell. Biol. 13: 5794-5804.

Zetterström, R.H., Solomin, L., Mitsiadis, T., Olson, L., and Perlmann, T. 1996a. Retinoid X receptor heterodimerization and developmental expression distinguish the orphan nuclear receptors NGFI-B, Nurr1 and Nor1. Mol. Endocrinol. 10: 1656-1666.

Zetterström, R.H., Williams, R., Perlmann, T., and Olson, L. 1996b. Cellular expression of the immediate early transcription factors Nurr1 and NGFI-B suggests a gene regulatory role in several brain regions including the nigrostriatal dopamine system. Mol. Brain Res. 41: 111-120.

Zetterström, R.H., Solomin, L., Jansson, L., Hoffer, B.J., Olson, L., and Perlmann, T. 1997. Dopamine neuron agenesis in Nurr1-deficient mice. Science 276: 248-250.

Zetterström, R.H., Lindqvist, E., Mata de Urquiza, A., Tomac, A., Eriksson, U., Perlmann, T., and Olson, L. 1999. Role of retinoids in the CNS: Differential expression of retinoid binding proteins and receptors and evidence for presence of retinoic acid. Eur. J. Neurosci. 11: 407-416. 


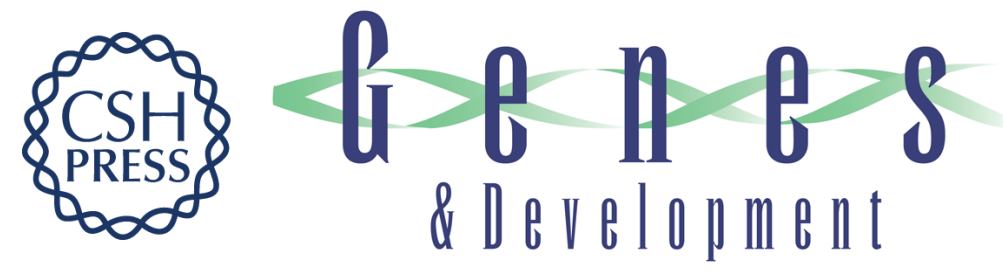

\section{Nurr1-RXR heterodimers mediate RXR ligand-induced signaling in neuronal cells}

Åsa Wallén-Mackenzie, Alexander Mata de Urquiza, Susanna Petersson, et al.

Genes Dev. 2003, 17:

Access the most recent version at doi:10.1101/gad.276003

References This article cites 61 articles, 22 of which can be accessed free at: http://genesdev.cshlp.org/content/17/24/3036.full.html\#ref-list-1

License

Email Alerting

Receive free email alerts when new articles cite this article - sign up in the box at the top Service right corner of the article or click here.

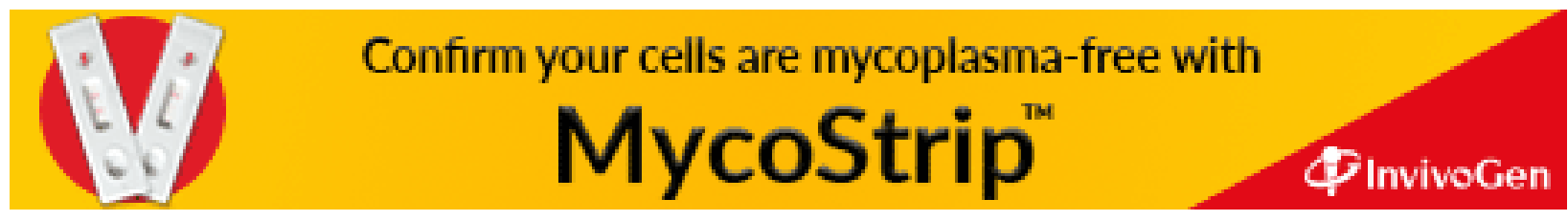

